\title{
DETERMINAN INTENSI KEPATUHAN WAJIB PAJAK PELAKU BISNIS ONLINE BERDASARKAN THEORY OF PLANNED BEHAVIOR
}

\section{Windi Ariesti Anggraeni, Muhammad Dahlan, dan Ivan Yudianto}

Fakultas Ekonomi dan Bisnis Universitas Padjadjaran

Email: windi17004@mail.unpad.ac.id, muhammad.dahlan@unpad.ac.id, dan ivan.yudianto@unpad.ac.id

\section{Abstract}

This study aims to determine and analyze the determinants of intention of online business taxpayer compliance based on the concept of theory of planned behavior (theory of planned behavior) which is proxied as attitudes, subjective norms and behavior control. This study uses 100 respondents of online businesses that have been registered as taxpayers. Data analysis techniques to test hypotheses using multiple regression analysis. The analysis shows that attitudes, subjective norms, and behavioral control have a significant and positive effect on compliance intentions.

Keywords: theory of planned behavior, attitude, subjektive norm, behavioral control

\section{Abstrak}

Penelitian ini bertujuan untuk mengetahui dan menganalisis determinan intensi kepatuhan wajib pajak pelaku bisnis online berdasarkan konsep theory of planned behavior (teori perilaku terencana) yang diproksikan sebagai sikap, norma subjektif dan kontrol perilaku. Penelitian ini menggunakan sampel dari pelaku bisnis online yang telah terdaftar sebagai Wajib Pajak sebanyak 100 responden. Teknik analisis data untuk menguji hipotesis menggunakan analisis regresi berganda. Hasil analisis menunjukkan bahwa sikap, norma subjektif, dan kontrol perilaku secara parsial dan simultan berpengaruh signifikan dan positif terhadap intensi kepatuhan wajib pajak.

Kata Kunci: teori perilaku terencana, sikap, norma subjektif, kontrol perilaku

\section{Pendahuluan}

Di Indonesia sumber utama pendapatan yang diperoleh dari rakyat ialah pajak. Pajak merupakan iuran wajib dari rakyat yang dipungut oleh negara berdasarkan undang-undang dan digunakan untuk mencapai kesejahteraan umum. Besarnya kontribusi dalam pajak dapat menjamin kestabilan tersedianya sumber penerimaan. Dalam RAPBN 2019, Indonesia menempatkan pajak sebagai sumber pendapatan utama, yakni sebesar 1.781 triliun rupiah atau sebesar $83,1 \%$ dari sumber pendapatan negara. Setiap tahun anggaran belanja Negara kita bergantung pada penerimaan pajak, hal ini

$\begin{array}{ll}\text { How to cite: } & \text { Anggraeni, Windi Ariesti., Muhammad Dahlan, dan Ivan Yudianto (2021) Determinan Intensi } \\ & \text { Kepatuhan Wajib Pajak Pelaku Bisnis Online Berdasarkan Theory of Planned Behavior Syntax } \\ & \text { Literate: Jurnal Ilmiah Indonesia. 6(4). http://dx.doi.org/10.36418/syntax-literate.v6i4.1007 } \\ \text { E-ISSN: } & \text { 2548-1398 } \\ \text { Published by: } & \text { Ridwan Institute }\end{array}$


tercermin dari kontribusi perpajakan yang terus meningkat dari tahun ke tahun. Namun, penerimaan pajak selama ini masih belum mencapai target.

Dibandingkan negara lain, angka tax ratio Indonesia juga saat ini masih terbilang rendah. Berdasarkan data yang dirilis oleh (OECD, 2019), pada tahun 2017 rasio pajak Indonesia berada di bawah rata-rata rasio pajak negara anggota OECD $(34,2 \%)$, yakni hanya sebesar $11,5 \%$. Kemenkeu juga mengungkapkan tax ratio Indonesia selama 5 tahun terakhir masih berada di bawah 15\%, dan pada tahun 2018 berada di angka 10,4\%, sementara negara tetangga seperti Malaysia berada di angka 13,8\%, Filipina 13,7\%, Singapura 14,3\%, Kamboja 15,3\% dan Thailand 15,7\%. Selfassessment system yang selama ini dilaksanakan guna memudahkan wajib pajak dalam melaksanakan kewajiban perpajakannya dirasa belum optimal. Hal ini bisa terlihat dari tingkat rasio kepatuhan yang sampai saat ini masih belum menemui sasaran. Guna meningkatkan rasio pajak, tentu diperlukan kesadaran masyarakat akan pajak itu sendiri demi kemajuan perekonomian negara.

"Indonesia merupakan pasar terbesar e-commerce di Asia Tenggara" (DBS, 2017). Menurut data (Euromonitor, 2014), "penjualan online Indonesia mencapai US\$ 1,1 miliar atau lebih tinggi dibanding Thailand dan Singapura". Di Indonesia, 83\% transaksi e-commerce melibatkan sosial media yang cenderung unregulated, sementara transaksi e-commerce akan terus meningkat, sehingga hal ini seharusnya mampu meningkatkan pemasukan bea dan cukai serta pajak (Apindo, 2019). Berdasarkan peraturan yang diterbitkan (Pajak., 2019), secara regulasi, aspek perpajakan antara transaksi perdagangan elektronik dengan perdagangan konvensional tidaklah berbeda. Hal ini sebagaimana dikatakan (Nufransa, 2014) bahwa "tidak ada perbedaan tarif pajak yang dikenakan atas transaksi melalui e-commerce dengan transaksi melalui cara konvensional. Sehingga para pedagang yang berjualan secara konvensional ataupun melalui e-commerce sama-sama harus melaksanakan kewajiban perpajakannya."

Banyak penelitian yang telah dilakukan terkait faktor-faktor yang mempengaruhi kepatuhan wajib pajak. Adapun beberapa penelitian terdahulu menjadikan Theory of Planned Behaviour (TPB) atau teori perilaku terencana dari (Ajzen, 2012) sebagai dasar teori dalam melakukan penelitian tentang kepatuhan wajib pajak. TPB merupakan teori penting yang hadir dalam ruang lingkup sosial psikologi dan mencoba menjelaskan perilaku manusia (Benk, 2011). Namun demikian, kemampuan untuk melakukan perilaku tertentu tergantung pada fakta bahwa individu memiliki tujuan terhadap suatu perilaku tersebut. Secara garis besar model TPB dapat bermanfaat dalam mengidentifikasi bagaimana dan ke mana mengarahkan strategi-strategi untuk perubahan perilaku dan juga untuk menjelaskan pada tiap aspek penting beberapa perilaku manusia seperti mengapa seseorang mau berperilaku patuh. Dalam hal ini, TPB dapat menjelaskan tentang perilaku kepatuhan wajib pajak terhadap peraturan perpajakan yang dapat dipengaruhi oleh sikap, norma subjektif, dan kontrol perilaku yang dipersepsikan.

(Efebera, Hayes, Hunton, \& O’Neil, 2004) mengatakan bahwa terdapat hubungan positif yang signifikan antara niat kepatuhan pajak dengan vertical equity dan 
horizontal equity, dan legal sanctions serta normative expectation memiliki pengaruh terhadap intensi (niat) kepatuhan pajak. Hal ini sejalan dengan (Bobek \& Hatfield, 2003) yang mengatakan bahwa sikap dan norma subjektif berpengaruh terhadap kepatuhan pajak. Penelitian (Fajar, 2014; Mas' ud, 2012; Oktaviani, 2015) juga menunjukkan bahwa sikap dan kontrol keperilakuan berpengaruh terhadap niat wajib pajak dalam mematuhi kewajiban perpajakannya. (Guerra \& Harrington, 2018) mengemukakan bahwa attitude berpengaruh terhadap ketidakpatuhan wajib pajak. Sementara (Benk, 2011) mengatakan bahwa tidak ada hubungan yang signifikan antara persepsi ekuitas (sikap) dari wajib pajak dengan niat kepatuhan pajak. Sedangkan subjek normatif dan sanksi hukum (kontrol perilaku) memiliki pengaruh dalam menentukan niat kepatuhan pajak. Penelitian (Venusita \& Dyan, 2013) juga menunjukkan bahwa ada pengaruh norma subyektif terhadap kepatuhan wajib pajak. Sementara penelitian (Anjani \& Restuti, 2016; Oktaviani, 2015) menunjukkan bahwa norma subjektif tidak berpengaruh terhadap niat wajib pajak untuk berperilaku patuh. Sikap, norma subyektif, dan kontrol perilaku yang dipersepsikan juga tidak memiliki interaksi yang saling berpengaruh satu sama lain (Anjani \& Restuti, 2016).

Berdasarkan latar belakang di atas, peneliti bermaksud menjadikan theory of planned behavior sebagai dasar teori untuk mengetahui pengaruh sikap, norma subjektif, dan kontrol perilaku terhadap intensi kepatuhan wajib pajak pelaku bisnis online.

\section{Metode Penelitian}

Metode yang digunakan pada penelitian ini adalah metode penelitian kuantitatif. Teknik pengumpulan data menggunakan studi kepustakaan dan survey. Jenis data yang digunakan adalah data primer dengan sumber data yang diperoleh dari sebaran kuesioner kepada 100 responden. Teknik analisis data untuk menguji hipotesis menggunakan analisis regresi berganda dengan bantuan program Statistical Package of Social Science Version 23.

\section{a. Variabel Bebas $(\mathbf{X})$}

Variabel bebas dalam penelitian ini adalah faktor-faktor yang mempengaruhi kepatuhan wajib pajak yang terdiri dari sikap (attitudes), norma subjektif (subjective norms), dan kontrol perilaku (perceived behavior controls) (Supriyono, 2016).

1. Sikap (X1)

Sikap diukur dengan mengidentifikasi sikap wajib pajak dalam perilakunya, dengan penilaian tanggapan responden terhadap keadilan tarif pajak yang dikenakan, jumlah pajak yang mereka bayar dibandingkan dengan orang yang berpenghasilan lebih tinggi, kontribusi wajib pajak sesamanya, pemanfaatan uang pajak oleh pemerintah, perasaan diuntungkan oleh sistem perpajakan, dan kepuasan terhadap layanan/fasilitas yang diperoleh.

2. Norma subjektif (X2)

Norma subjektif diukur dengan mengidentifikasi norma sosial dan moral (Efebera et al., 2004). Norma subyektif mengacu pada norma sosial dan norma 
moral. Norma sosial direpresentasikan oleh pengaruh dari kerabat, orang terdekat/rekan, pertugas pajak, dinas/pemerintah terkait, dan media cetak/elektronik. Norma moral dinilai atas kesadaran yang ada pada diri individu, dalam hal ini berkaitan dengan tanggapan mereka terhadap kewajiban perpajakan itu sendiri, antara lain adanya perasaan bersalah ketika tidak melaporkan pajak, melanggar prinsip pribadi, dan berkeyakinan bahwa tidak melaporkan penghasilan kepada pihak pajak adalah tindakan yang salah.

3. Kontrol perilaku (X3)

Kontrol perilaku diukur dengan mengidentifikasi efek sanksi hukum yang direpresentasikan dengan adanya risiko dan besarnya hukuman (Efebera, et al, 2015). Wajib pajak dapat melakukan kontrol perilaku dengan mengidentifikasi risiko apa yang dapat ia terima di kemudian hari ketika patuh atau tidak patuh terhadap peraturan perpajakan. Adapun, besarnya hukuman mengacu pada besarnya atau beratnya sanksi atau denda yang akan diterima jika ia tidak berperilaku patuh.

\section{b. Variabel Terikat (Y)}

Variabel terikat (dependen) dalam penelitian ini adalah intensi atau niat kepatuhan wajib pajak. Niat kepatuhan wajib pajak diidentifikasi dengan melihat adanya kecenderungan dan keputusan wajib pajak untuk selanjutnya bertindak patuh.

Pengambilan sampel pada penelitian ini dilakukan dengan metode Probability Sampling dengan teknik Simple Random Sampling. Sampel pada penelitian ini adalah sebanyak 100 wajib pajak pelaku bisnis online.

Dalam pengukurannya, variabel ini menggunakan skala likert. Dengan skala likert, maka variabel yang akan diukur dijabarkan menjadi indikator variabel di mana responden dapat menentukan jawaban dengan mengikuti pertanyaanpertanyaan yang telah disusun melalui indikator-indikator yang ditentukan. Dalam skala likert setiap jawaban diberi bobot tertentu, dalam penelitian ini bobot terendah diberi nilai 1 dan bobot tertinggi 5 .

Analisis statistik yang dilakukan pada penelitian ini adalah teknik analisis regresi ganda. Kerangka hubungan dapat dibuat melalui persamaan struktural berikut:

$$
\mathrm{Y}=\mathrm{a}+\mathrm{b}_{1} \mathrm{X}_{1}+\mathrm{b}_{2} \mathrm{X}_{2}+\mathrm{b}_{3} \mathrm{X}_{3}+\mathrm{e}
$$

Keterangan:

$\mathrm{Y}=$ subjek variabel terikat yang diproyeksikan

$\mathrm{a}=$ konstanta

$\mathrm{b}=$ koefisien determinasi

$\mathrm{X}_{1}, \mathrm{X}_{2}, \mathrm{X}_{3}=$ variabel bebas

$\mathrm{e}=$ koefisien variabel lain yang tidak diteliti 


\section{Hasil dan Pembahasan}

\section{A. Statistik Deskriptif}

Jumlah kuesioner yang terkumpul sebanyak 100 buah. Berdasarkan gender, responden bergender laki-laki sebanyak $57 \%$ dan perempuan $43 \%$. Berdasarkan usia, responden yang berusia 20-30 tahun mendominasi sebesar 56\%, selanjutnya oleh responden dengan usia 31-40 tahun sebesar 22\%, 41-50 tahun sebesar 16\%, dan sisanya responden berusia di atas 50 tahun sebesar $6 \%$. Berdasarkan latar belakang pendidikan terakhir responden yang terbanyak adalah tingkat pendidikan S1, yakni sebesar 54\%. Urutan kedua yaitu tingkat pendidikan SMA sebesar 30\%. Sisanya Diploma sebesar 9\%, S-2 6\%, dan SMP 1\%. Berdasarkan bidang usaha responden, didominasi sebesar $62 \%$ oleh responden dengan bidang usaha kuliner, fashion sebanyak $24 \%$, sisanya bidang jasa $8 \%$, produk digital $3 \%$, dan lainnya $3 \%$. Adapun untuk penggunaan media online dalam transaksi bisnisnya, sebanyak $82 \%$ dari 100 orang responden menggunakan media sosial (seperti instagram, facebook, dll), kemudian sebesar $26 \%$ responden memanfaatkan juga marketplace (seperti tokopedia, lazada, dll), dan sebesar 9\% menggunakan web site. Masing-masing responden tidak terpaku pada satu media saja, melainkan beberapa media online digunakan untuk memasarkan produk dan melakukan transaksi bisnisnya.

\section{B. Hasil Pengujian dan Pembahasan}

Penelitian ini menggunakan hipotesis dua arah, kaidah keputusan hipotesisnya adalah didasarkan pada nilai sig, apabila lebih kecil dari 0,05 maka Ha diterima. Sebaliknya, apabila nilai $s i g \geq 0,05$ maka Ha ditolak.

Di bawah ini disajikan tabel yang menunjukkan hasil uji parsial untuk variabel $\mathrm{X} 1, \mathrm{X} 2$ dan X3 terhadap Y.

Tabel 1

Hasil Uji Parsial (Uji t)

\begin{tabular}{lcccc}
\hline \multicolumn{1}{c}{ Variabel } & Beta & t & Sig. & Keputusan \\
\hline Sikap (X1) & .239 & 2.647 & .009 & Diterima \\
\hline Norma Subjektif (X2) & .307 & 3.413 & .001 & Diterima \\
\hline Kontrol Perilaku (X3) & .367 & 3.445 & .001 & Diterima \\
\hline
\end{tabular}

Hasil uji hipotesis pada penelitian ini menunjukkan bahwa sikap berpengaruh signifikan dan positif terhadap niat kepatuhan. Hal ini diperoleh dari nilai sig sebesar 0,009 yang lebih kecil dari 0,05 dan nilai beta yang positif. Hasil penelitian ini menunjukkan bahwa semakin baik sikap wajib pajak terhadap peraturan perpajakan maka niat untuk berperilaku patuh pun semakin tinggi.

Norma subjektif dengan nilai Sig 0,001 $<0,05$ menunjukkan bahwa norma subjektif berpengaruh signifikan dan positif terhadap niat kepatuhan. Hasil penelitian ini menunjukkan bahwa semakin baik norma subyektif wajib pajak, maka semakin besar niat wajib pajak untuk berperilaku patuh. 
Berdasarkan hasil uji parsial untuk kontrol perilaku juga diperoleh nilai Sig $0,001<0,05$ yang berarti kontrol perilaku berpengaruh positif dan signifikan terhadap niat kepatuhan. Hasil penelitian ini menunjukkan bahwa semakin besar kontrol perilaku wajib pajak, maka semakin besar niat wajib pajak untuk berperilaku patuh.

Dalam analisis ini, dianalisis pula besarnya koefisien determinasi. Uji koefisien determinasi dalam penelitian ini digunakan untuk melihat besar pengaruh yang diberikan variabel independen terhadap setiap perubahan yang terjadi pada variabel dependen.

\section{Tabel 2}

Hasil Koefisien Determinasi

\begin{tabular}{crcr}
\hline & R Square & $\begin{array}{c}\text { Adjusted R } \\
\text { Square }\end{array}$ & $\begin{array}{c}\text { Sig. F } \\
\text { Change }\end{array}$ \\
\hline Sub Struktural & .691 & .681 & .000 \\
\hline
\end{tabular}

Hasil pengujian untuk sub struktural menunjukkan $\mathrm{R}_{\text {square }}$ atau $\mathrm{R}^{2}$ sebesar 0,691 atau 69,1\%. Artinya dapat dikatakan bahwa kontribusi variabel sikap (X1), norma subjektif (X2), dan kontrol perilaku (X3) secara simultan yang langsung mempengaruhi niat kepatuhan (Y) adalah sebesar 69,1\%. Sedangkan sisanya sebesar $30,9 \%$ merupakan pengaruh yang datang dari faktor-faktor lain yang tidak diteliti pada penelitian ini.

\section{Pembahasan}

Pada penelitian ini diperoleh bahwa persepsi yang dimiliki responden terhadap variabel sikap termasuk dalam kategori cukup. Semakin tinggi skor mengindikasikan semakin tinggi konsekuensi positif yang dirasakan oleh responden. Dalam penelitian ini, responden merasa cukup atas keadilan tarif yang dikenakan, jumlah pajak yang dibayarkan apabila dibandingkan dengan wajib pajak lain, kemudahan yang dirasakan atas sistem perpajakan saat ini, ketepatan pemerintah dalam memanfaatkan anggaran atas penerimaan pajak, dan kepuasan terhadap layanan atau feedback yang diperoleh dari pemerintah atas pajak yang telah dibayarkan. Berdasarkan hasil analisis tersebut, penelitian ini menunjukkan bahwa ketika wajib pajak menunjukkan sikap yang baik terhadap perpajakan itu sendiri, maka kecenderungan dan keputusan mereka untuk mematuhi kewajiban perpajakannya juga besar.

Penelitian ini juga menunjukkan bahwa persepsi yang dimiliki responden terhadap variabel sikap termasuk dalam kategori cukup. Semakin tinggi skor mengindikasikan semakin tinggi norma sosial dan norma moral yang dirasakan oleh responden. Norma sosial berkaitan dengan pengaruh kerabat/keluarga, rekan/orangorang terdekat, dan media (cetak/elektronik) yang dapat mendorong seseorang untuk mempertimbangkan akan berperilaku tertentu. Di antara lima indikator yang diidentifikasi dapat menjadi faktor pendorong seorang wajib pajak berperilaku 
patuh, pengaruh dinas pemerintah terkait memiliki pengaruh yang cukup tinggi. Responden mengatakan bahwa adanya prosedur baru dalam melakukan perizinan usaha mendorong mereka untuk mendaftarkan diri sebagai wajib pajak. Sementara keluarga, rekan, dan petugas pajak masih kurang mendorong atau mengingatkan untuk mematuhi kewajiban perpajakan. Adapun media elektronik seperti situs internet, media sosial, dan SMS menjadi salah satu upaya pemerintah yang mereka terima lewat kampanye sadar pajak. Begitu juga dengan media cetak seperti baliho merupakan bentuk kampanye sadar pajak dari pemerintah. Sementara norma moral berkaitan dengan prinsip individu itu sendiri, seperti bagaimana perasaan individu ketika melakukan suatu tindakan, apakah ada perasaan bersalah ketika melakukan suatu hal penyimpangan, apakah melanggar prinsip pribadi, dan tentang apakah suatu tindakan tersebut termasuk hal yang benar atau salah menurut persepsi dirinya. Responden pada penelitian ini memiliki norma moral yang cukup tinggi. Berdasarkan hasil analisis tersebut, penelitian ini menunjukkan bahwa ketika norma subjektif yang dimiliki wajib pajak baik, maka kecenderungan dan keputusan mereka untuk mematuhi kewajiban perpajakannya juga besar.

Kontrol perilaku yang dilakukan responden terkait dengan bagaimana responden mengidentifikasi risiko dan sanksi yang dapat dikenai di kemudian hari. Dalam hal kepatuhan pajak, pengendalian wajib pajak tersebut direpresentasikan oleh adanya kemungkinan diketahui oleh pihak pajak, kemudian diperiksa bahkan sampai ditangkap, selanjutnya berkaitan dengan seberapa besar kemungkinan memperoleh masalah dengan fiskus, kemungkinan dikenai sanksi hingga berat sanksi yang diterima. Berdasarkan hasil analisis tersebut, penelitian ini menunjukkan bahwa semakin tinggi kemampuan wajib pajak dalam mengendalikan tindakannya maka akan semakin tinggi pula niat wajib pajak untuk berperilaku patuh terhadap kewajiban perpajakannya.

\section{Kesimpulan}

Berdasarkan hasil pembahasan dan uraian di atas, maka dapat ditarik kesimpulan bahwa sikap memiliki pengaruh yang positif dan signifikan terhadap intensi kepatuhan wajib pajak. Semakin baik sikap wajib pajak maka semakin besar niat wajib pajak untuk berperilaku patuh. Norma subjektif juga memiliki pengaruh yang positif dan signifikan terhadap intensi kepatuhan wajib pajak. Semakin baik norma subyektif wajib pajak, maka semakin besar niat wajib pajak untuk berperilaku patuh. Begitu juga dengan kontrol perilaku yang memiliki pengaruh yang positif dan signifikan terhadap intensi kepatuhan wajib pajak. Semakin besar kontrol perilaku wajib pajak, maka semakin besar niat wajib pajak untuk berperilaku patuh dalam memenuhi kewajiban perpajakannya..

Rekomendasi bagi pemerintah, khususnya DJP, dapat meningkatkan kepercayaan wajib pajak terhadap pemerintah dengan beberapa cara, antara lain: adanya transparansi penggunaan anggaran melalui platform yang dapat dengan mudah diakses oleh masyarakat, seperti web site, infografis melalui media sosial, ataupun melalui 
media cetak. Selain itu juga, dapat dilakukan peningkatan pelayanan di lingkungan kantor pelayanan pajak khususnya dalam hal memberikan arahan kepada para wajib pajak yang belum mengetahui prosedur pelaporan pajak dengan benar. Pihak pajak juga dapat terus melakukan sosialisasi melalui penyuluhan, seminar, maupun pelatihan praktis dalam rangka mengedukasi masyarakat akan pentingnya mematuhi kewajiban perpajakannya.

Bagi peneliti selanjutnya, dapat menambahkan indikator lain sebagai instrumen yang dapat menjelaskan variabel-variabel yang berpengaruh terhadap intensi kepatuhan wajib pajak. 


\section{BIBLIOGRAFI}

Ajzen, I. (2012). The Theory of Planned Behavior. London: Sage. Google Scholar

Anjani, Devira Nourma, \& Restuti, M. I. Mitha Dwi. (2016). Analisis Faktor-Faktor Kepatuhan Wajib Pajak Orang Pribadi Pelaku Usaha Pada KPP Pratama Salatiga. BAKI (Berkala Akuntansi Dan Keuangan Indonesia), 1(2). Google Scholar

Apindo. (2019). Apindo Soroti Fenomena E-Commerce Transaction of Cross Border. Google Scholar

Benk, S; A. F. Cakmak; dan T. Budak. (2011). An Investigation of Tax Compliance Intention: A Theory of Planned Behavior Approach. European Journal of Economics, Finance and Administrative Science. Google Scholar

Bobek, Donna D., \& Hatfield, Richard C. (2003). An investigation of the theory of planned behavior and the role of moral obligation in tax compliance. Behavioral Research in Accounting, 15(1), 13-38. Google Scholar

DBS. (2017). Mendorong Pengembangan Ekonomi Digital di Luar Jawa. Google Scholar

Efebera, Henry, Hayes, David C., Hunton, James E., \& O’Neil, Cherie. (2004). Tax compliance intentions of low-income individual taxpayers. In Advances in Accounting Behavioral Research. Emerald Group Publishing Limited. Google Scholar

Euromonitor. (2014). E-Commerce in Indonesia. Google Scholar

Fajar, Muhammad. (2014). Analisis Faktor-Faktor Yang Berpengaruh Terhadap Tax Compliance Penyetoran SPT Masa Dengan Niat Sebagai Variabel Intervening (Survei pada PKP yang Terdaftar di KPP Pratama Surakarta. Universitas Muhammadiyah Surakarta. Google Scholar

Guerra, Alice, \& Harrington, Brooke. (2018). Attitude-behavior consistency in tax compliance: A cross-national comparison. Journal of Economic Behavior \& Organization, 156, 184-205. Google Scholar

Mas' ud, Muchlis H. (2012). Pengaruh Sikap, Norma-Norma Subyektif dan Kontrol Perilaku Yang Dipersepsikan Nasabah Bank Terhadap Keinginan Untuk Menggunakan Automatic Teller Machine (Atm) Bank Bca di Kota Malang. Jurnal Manajemen Dan Akuntansi, 1(3). Google Scholar

Nufransa, Sakti Wira. (2014). Buku Pintar Pajak E-Commerce. Jakarta: Visi Media. Google Scholar

OECD. (2019). Tax to GDP Ratio. 
Windi Ariesti Anggraeni, Muhammad Dahlan, dan Ivan Yudianto

Oktaviani, R. M. (2015). Determinant Of Tax Compliace With Intention As Mediation From Planned Behaviour Theory Perspective. Jurnal Bisnis Dan Ekonomi (JBE), 22(1). Google Scholar

Pajak., Direktorat Jenderal. (2019). Peraturan Perlakuan Perpajakan e-commerce Terbit, Tingkatkan Kepastian dan Keadilan Bagi Semua Pelaku Usaha. Siaran Pers nomor SP-04/2019.

Supriyono, R. A. (2016). Akuntansi Keperilakuan (1st ed.; Mash, Ed.). Yogyakarta: Gadjah Mada University Press. Google Scholar

Venusita, Lintang, \& Dyan, Femka. (2013). Analisis Pengaruh Sikap, Norma Subyektif, Dan Kontrol Keperilakuan Terhadap Perilaku Kepatuhan Wajib Pajak Restoran Di Surabaya. AKRUAL: Jurnal Akuntansi, 5(1), 59-74. Google Scholar

\section{Copyright holder:}

Windi Ariesti Anggraeni, Muhammad Dahlan, dan Ivan Yudianto (2021)

First publication right:

Journal Syntax Literate

This article is licensed under:

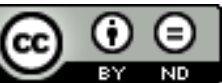

